\title{
Entrepreneurship and Financial Crisis: A Critical Investigation of Entrepreneurship Prospects and Opportunities That Lie Behind the Financial Crisis
}

\author{
Evangelia Fragouli ${ }^{1}$, Nikolaos Giannakovitis ${ }^{2}$ \\ ${ }^{1}$ Business School, University of Dundee, Dundee, UK \\ ${ }^{2}$ Hellenic Open University, Patra, Greece
}

Email address:

e.fragouli@dundee.ac.uk (E. Fragouli), std097465@ac.eap.gr (N. Giannakovitis)

To cite this article:

Evangelia Fragouli, Nikolaos Giannakovitis. Entrepreneurship and Financial Crisis: A Critical Investigation of Entrepreneurship Prospects and Opportunities That Lie Behind the Financial Crisis. International Journal of Economic Behavior and Organization.

Vol. 5, No. 2, 2017, pp. 36-53. doi: 10.11648/j.ijebo.20170502.11

Received: September 12, 2016; Accepted: February 28, 2017; Published: March 15, 2017

\begin{abstract}
The aim of this study is to identify the factors which affect the decision of setting up new business in Greece, as well as identifying parameters associated with entrepreneurship in the period of the economic crisis. In this study, through a critical review of the literature and primary research, an analysis of a set of variables regarding enterpreneurship takes place, such as the sources of business financing, the institutional environment, as reflected in the role of clusters and business education, as well as the incentives entrepreneurs have in order to set up a business in the current conditions. The study shows that entrepreneurship is not a fixed condition, but a dynamic process, it is the most important source of potential growth, given that public expenditure have been cut significantly, and private consumption has shrunk.
\end{abstract}

Keywords: entrepreneurship, financing, entrepreneurship motivation

\section{Introduction}

\subsection{Background and Rationale of the Study}

The economic crisis in Greece is a fact since 2008. Greece, from 2008 up to the current time, has a recession in which the country's GDP has fallen by about $25 \%$. At the same time, unemployment has risen sharply, especially at younger ages, where the unemployment rate is $51 \%$, while more than $50 \%$ is recorded in the long term unemployment. A sector of the economy that has significantly affected is that of entrepreneurship and its determinants. The purpose of this study is to explore the extent to which the economic crisis has affected entrepreneurship in Greece, applying literature review and primary research.

In order a country to achieve economic growth, the activation of private investment is required, to strengthen existing businesses, but mainly with the establishment of new companies. Although the importance of the activation of entrepreneurs has been highlighted, both in Greece and the $\mathrm{EU}$, there are a number of factors that act as obstacles for investors to set new businesses. These factors have to be identified and examined, in order the government and institutions (such as banks, institutional investors and universities) to take measures, in order to help entrepreneurship. Also, there is a need to analyze the motives of entrepreneurship in the current environment: are entrepreneurs in Greece motivated by need, since they have not any alternative to have income and employment, or they are motivated by the business opportunities they have identified? Do they believe that the current crisis is a threat or an opportunity?

\subsection{Research Questions}

The research questions of the study are the following:

- Regarding the motives of entrepreneurship, the research question is: which are the main incentives for entrepreneurs to establish their business? Do entrepreneurs believe that the current crisis is a threat or an opportunity?

- Regarding the issue of entrepreneurship financing, the 
research questions are: which are the main sources of new business financing and which is the degree of adoption of forms of financing other than bank loans?

- Regarding the issue of the institutional environment to entrepreneurship, the research question is: are institutions (clusters, universities, government agencies) involved in the concept and the implementation of the business idea?

- Regarding the issue of the preparation of entrepreneurs for the establishment of their companies, the research question is: do new Greek companies have prepared a business plan?

\subsection{Research Aim and Objectives}

The main objective of the study is to identify the factors which affect the decision of setting up new businesses in Greece, as well as the factors associated with entrepreneurship in the period of the economic crisis. Within the main objective of the study, there is a series of parallel objectives, such as:

- The identification of financing sources used by entrepreneurs and the degree of the adoption of financing methods

- The investigation of the role of the institutional environment

- The examination of the level of entrepreneurs' preparation, as indicated by the existence of a business plan

\subsection{Contribution of the Study}

Although the international literature and the institutions such as the IMF and OECD, have underlined the importance of entrepreneurship for achieving positive growth rates, however, the motives to establish a company during an economic crisis have to be further explored. This issue is crucial for the current economic environment in Greece, since it has to be identified whether entrepreneurs are establishing their company out of need, due to the fact that there are no other alternatives or they are establishing a company in order to explore a business opportunity, because of a business idea. The study contributes to the academic literature, since not only analyses the trends of the "push" or "pull" entrepreneurship during a crisis but also identifies the factors of entrepreneurship during a crisis.

\subsection{Methodology of the Study}

The methodology of this study is based on quantitative primary research and a critical review of the literature. The validity of the sources is a key concern of the study; therefore all of the articles are from internationally renowned scientific journals, and books from well-established international publishers, with authors receiving general recognition and acceptance. Besides the literature review, the study will contain primary research, based on questionnaires. The specific research type has been chosen because of the nature of the study, since the main research question is about the identification of the factors which affect the decision of establishing a new company, as stated by the entrepreneurs themselves.

\section{Literature Review}

\subsection{Conceptual Framework of Entrepreneurship}

The concept of entrepreneurship is already set in the 18th century. Specifically, Richard Cantillon (1680-1734) was the first scientist who has focused on the concept of the entrepreneur and was the first to recognize that there is a business function in the economic system. Entrepreneurs appeared to economic theory as determinants of the economic system. Cantillon recognized the following three types of the economic participants: i) the landlords capitalist's ii) entrepreneurs-speculators and iii) employees in paid employment. The perception of the market includes the self-regulated network of exchange arrangements. The entrepreneur has a central role in this system because he is responsible for the entire exchange and circulation in the economy. The class of entrepreneurs offers to the economic system the balance of supply and demand (Stokes et al., 2010).

Shane and Venkatraman (2000) have defined entrepreneurship as a process by which opportunities are discovered, evaluated and exploited in order to create future goods and services. Several key issues are arising from the use of this definition. For example, the definition does not imply that the entrepreneur is the founder of the company, a common assumption in research on entrepreneurship, and highlights the fact that new and innovative ideas for products and services can come from anywhere in the hierarchy and not necessarily from the top (i.e., business owners or founders). Furthermore, it supports the interpretation of entrepreneurship as a "process", and not as an isolated event, action or decision. For example, the decision to create and organize a new business, while important, is only part of a series of measures to be taken for the effective discovery, evaluation and exploitation of an opportunity. Lastly, the definition recognizes that entrepreneurship is based on "creativity", which may include not only the discovery of new ideas and knowledge, but also the setting of resources in new ways. There is no minimum limit on "creativity" to be followed in order to qualify as enterprise and the degree of creativity involved in entrepreneurship varies depending on the types of recombination and reallocation of resources.

Although there is not a widely accepted definition of entrepreneurship, however, there seems to be agreement on the view that entrepreneurship is the creation of something new (Reynolds, 1991). Some authors have argued that entrepreneurship is essentially the creation of new organizations (Gartner, 1988), while Davidsson (2004) summarize the view that entrepreneurship exists to identify and exploit opportunities and the creation of new economic activity.

Another recent definition is given by the European 
Commission (2003), which defines entrepreneurship as the mentality and the process of creation and development of economic activity combining risk-taking, creativity and/or innovation with appropriate management, within a new and/or existing organization.

Entrepreneurship is often associated with the dominant, reckless and independent trader who either is about to establish a company or he/she is aggressively seeking new opportunities for wealth creation, but this view of entrepreneurship is not universally accepted. Surveys have shown that entrepreneurs are presented with many different personal characteristics, while in many cases the empirical results lead to different conclusions. For example, Webster (1977) mentions five different types of entrepreneurs:

[1] The "Cantillon entrepreneur" which causes the change to create a monopoly in the market. This type is the classical view for entrepreneurs as people who can take high risks.[2] The "market maker", which opens new paths through innovations and basically invents his property. This allows him to dominate the market. [3] The "administrative entrepreneur," which is associated with a company, either as a founder, or regarding the company's restructuring. [4] The "SME owner" who wants the company to remain small and primarily he is having the business activity for his own or for the family members. [5] The 'independent entrepreneur', which creates without taking risks, encouraging others to invest in risky business ventures.

As Ahmad and Seymour (2012) note, the entrepreneurial activity includes the creative resources, the innovative capabilities and perceiving the opportunity, so according to the authors (Ahmad and Seymour, 2012) entrepreneurship is directly connected to the concept of innovation and creativity.

\subsection{Characteristics of the Entrepreneur}

The concept of "entrepreneur" is very difficult to be precisely determined. According to Jennigs (1994), the definitions that have been proposed are influenced by logic and methodology of their scientific field in which the analysis is made (mainly in economics, psychology and management). Despite the fact that there have been many common views on the definition of the entrepreneur, there is a lack of a common theoretical framework that can synthesize these views.

The views expressed in the literature about the concept of the entrepreneur can be grouped under two broad approaches: the economics approach and the humanistic approach. Several researchers argue that entrepreneurship came from economics. Verin (1982, mentioned in Filion, 2011), by examining the origins of the "entrepreneur" showed that the term has acquired its current meaning in the 17 th century. The word comes from the French verb "entreprendre" which means" I attempt". Casson and Wadson (2007) mention two general categories of entrepreneurs: the "managerentrepreneurs" and "innovative entrepreneurs". The first group includes the classical entrepreneur and the second category includes the approaches of Schumpeter (1934) as presented above. The fact is that for the interpretation of entrepreneurship requires knowledge of the personal characteristics of entrepreneurs. McClelland notes that the need for achievement is the main characteristic of the entrepreneur and he focused his research interest in the search for an ideal type of entrepreneur. McClelland (1961) notes that an entrepreneur is someone who has control over the production which is not intended only for his own consumption. By the late 1980s, the efforts of researchers focused on the entrepreneur definition by finding specific personal characteristics such as the need for autonomy, sovereignty and desire for control. Another approach taken was that of creating business profiles, composing personal characteristics. For example, Sexton and Bowman (1986), were able to distinguish entrepreneurs from managers based on a combination of features of the human personality as confident, optimism and independence.

So far it has not recorded a stable and specific set of characteristics of the human personality that distinguish entrepreneurs compared to the general population. As a result, since the early 1990 s, research focused more on action and activity of business and not on personal characteristics. For example, the analysis is focusing on how an entrepreneur configures the intention to set up a business. In these studies, the "intention" is defined as that condition of mind which directs attention to the experience and turns the action of the individual to a particular target. Indeed, research shows that the positive intentions of a person for specific behaviors predict with sufficient certainty the occurrence of this behavior. According to Chaston (2010) personal and social factors indirectly affect the behavior of the entrepreneur.

Also, there is an interest regarding whether entrepreneurs are more willing to risk-taking in relation to the rest of the population. Although there is no common definition of "risktaking", however, entrepreneurs are considered to be people who are attracted by the risk and invest in risky businesses that promise to maximize economic gains. However, surveys show that entrepreneurs do not show a greater propensity for risk-taking in relation to the general population (Mitchell et al., 2002). In practice, entrepreneurs have a tendency to classify doubtful and uncertain scenarios with more positive way because they use specific cognitive models. Undoubtedly, entrepreneurs are operating in a constantly changing environment and they learn through their business decisions and activities. According to Kuratko (2009), entrepreneurs should be considered as products of the environment in which they operate, while he notes that entrepreneurs reflect the characteristics of the period and the place they live and operate.

As noted by Reynolds (2014), the characteristics of the entrepreneur are both national and individual. Regarding national factors, there are economic characteristics, such as the GDP per capita and the Gini coefficient (related to income inequality), in a sense that, the higher the GDP per capita, the higher the growth rate and the lower the inequality, the more the resources an economy has in order to allow the creation of new businesses. Also, Reynolds (2014) 
mentions cultural characteristics, as well as individual characteristics, such as the gender-since females tend to have lower motivation to establish new companies than males-, the level of education, the work activity, etc. The factor of culture to entrepreneurship has been pointed out in the study of Wennberg et al. (2013), which they claim that some cultures have a higher level of fear of failure than other cultures and that fear is a key obstacle for people to establish a new company. Fear of failure, as well, is associated with lower levels of self-efficacy, which is "an individual's estimate of her (or his) ability to capably perform the roles and tasks to be successful as an entrepreneur" (Gatewood et al., 2014, p. 102), a decisive factor of entrepreneurship. Also, Welpe et al. (2012), in their analysis highlight as key factors of entrepreneurship the feelings of fear, joy and anger, as related to the evaluation of a business opportunity.

\subsection{Motives and Patterns of Entrepreneurship}

The different approaches and definitions of the concept of entrepreneurship trigger to clarify three specific points. The first point relates to the perception that the main motive for entrepreneurship is the financial gain. In fact, the economic profit is only one dimension of the generated value, while there are many factors that affect the profitability beyond a general and vague contribution of entrepreneurship. As mentioned in the previous paragraph there are other motives which underpin entrepreneurship, such as the need to achieve high targets (McClelland, 1961), the need for independence, etc. Finally, the entrepreneurial success can be judged by different criteria from the economic profit as $n$ create social value phenomenon known as social entrepreneurship.

The second point has to do with the fact that the historical background to the concept of entrepreneurship has shown that both the definitions and characteristics attributed to entrepreneurs mostly confined to the private sector. However, the image of courageous businessman-owner who achieves what no one else has accomplished is a remnant of the era where small businesses were the dominant form of private economic organization. The entrepreneurial approaches to individual events such as the creation of new business, introducing new products on the market are not able to interpret business activities conducted in organizations, a phenomenon known as corporate entrepreneurship. The business activity within organizations is a special management style which is based on identifying opportunities and is not limited by the size or age of the body nor of the sector in which the organization operates (Majumdar, 2008). Finally, the third point is that all approaches to the concept of the entrepreneur and entrepreneurship are not necessarily mutually exclusive to each other. The entrepreneur acts according to the prevailing conditions and opportunities presented (Thompson, 2004).

Regarding its business intentions about gender, several studies show that the intentions of people for entrepreneurship differentiated by gender, with men bearing stronger intentions than women (Muthaih \& Venkatesh, 2012), the which are less likely to start their own business. In particular, differences found in the intentions of both sexes, through the influence of social norms and perceived behavioral control. The perceived ability of an individual to establish a business activity and the attitudes and perceptions have for entrepreneurship are important predictive variables of its business intent. The differences between the sexes in the perceived self-efficacy in their professional pursuits has been the subject of many other research efforts. In most reflected their differentiation. With women have lower levels than men (Wennekers, 2006). Women also appear to be easier to lower their expectations for a professional career because of that they believe have reduced capabilities (Muthaih \& Venkatesh, 2012).

Even at secondary level differences were observed as to the perceived self-efficacy and entrepreneurial intentions. Especially boys showed stronger perceived self-efficacy and stronger intentions for establishing a business than girls (Chaston, 2010), and so it seems that entrepreneurship education cannot function as a filter to reduce the existing differences. Also, research has shown that university students have a higher level of self-efficacy, because they consider themselves more able to create a business, as they give less importance to the social norms and in total have stronger intentions (Winter et al., 1998).

\section{Economic and Financial Crisis}

\subsection{The Meaning of the Economic and Financial Crisis}

By economic crisis means the economic situation of a country which is manifested through a continuous decline in economic activity. Of course, the definition of economic crisis is assigned in different ways by several authors. According to Rosenthal et al. (1989), the economic crisis is "a serious threat to the existing structure, fundamental principles and norms of the social system, which requires the taking of critical decisions within a limited time and under uncertainty (Rosenthal et al., 1989).

According to the definition given by Sharpe (1963), the economic crisis is rendered as the period during which the market has a large downward move. Finally according to Erol et al. (2011), the economic crisis involves the disruption of economic balance and weakening of all economic factors due to sudden and unexpected events which occur due to local or global causes such as economic and administrative problems, corruption, disruption of the tax system, payment problems of external debt, the inability to import sufficient foreign capital, unemployment problems, or even natural disasters. Monetarists engage the economic crisis with the banking crisis (Friedman \& Schwatz, 1963). According to a broader definition, during an economic crisis, there is a sharp fall in asset prices, bankruptcies of large companies, etc. (Minsky, 1972). Mishkin (1992) provides an asymmetric information framework for the assimilation of the substance of the financial crisis. According to his definition, a financial crisis is a disruption in the financial markets where moral hazard is getting worse, and financial markets are not able to 
channel the funds effectively to those who bear the most productive investment opportunities. In consequence, the crisis has the potential to lead the economy away from equilibrium.

\subsection{Overview of the Recent Financial Crisis}

For most people, the global financial crisis was something they could not predict or even imagine. Ben Bernanke, chairperson of the FED after the crisis began, stated that "only a very, very few people could appreciate the bubble" (FCIC, 2011, p. 3). Also, Allan Greenspan, told to the same committee that "it was beyond the ability of regulators ever to foresee such a sharp decline (FCIC, 2011, p. 3). On the other hand, they were clear signals that the crisis was just a matter of time. Few months before the beginning of the crisis, total credit offered by banks was 1.5 times highest than the banks' deposits (Merrouche \& Nier, 2010). Also, credit to households in the USA had a record high of $100 \%$ of GDP, while loans to business were at almost $70 \%$ (Gualandri et al., 2009). Banks and other financial institutions, especially in the US, were widely using Asset Backed Securities (ABS), which, before the collapse were almost $90 \%$ of all securities issued. Due to deregulation, banks could use any kind of financial products, so many banks decided to use over-thecounter derivatives (Dodd, 2008), underestimating the risks of these instruments. Here, we have to underline that, the deregulation of the banking sector took place in the last years of the 1980's (Sherman, 2009) and, although this deregulation resulted in the stock market crash of 1987 , governments in the US and Europe decided a further deregulation of banks. At the same time, central banks chose to follow the policy of low-interest rates, allowing banks to borrow money, easy and at low cost and, in their turn, they were providing home loans. Subprime mortgages, which were $9 \%$ of total housing in 2003, grew to the $24 \%$ in 2007 (FCIC, 2011). Many households, which under normal circumstances they would not be accepted by banks to take a home loan took a loan without the ability to handle it. Banks provided loans which only guaranteed the expected increase in housing prices and attracted customers with low-interest rates, without informing these customers that these lowinterest rates were only for a two years and, after this period, customers would have to pay a higher interest rate.

Also, through the practice of securitization, banks were making a risk transfer and, at the same time, were having, even more, liquidity to offer more loans. The transfer of risk from banks to the public and investors through the securitization was a common practice. This transfer of risk allowed banks to lend almost everyone, despite their ability to repay the loans.

Regarding how much longer the system could grow only by the promise of rising housing prices and how much longer banks could borrow money through securitization, capital markets started to freeze. This led to contagion, since not the banks, nor the Special Purpose Vehicles (SPVs), which are firms specialized in the securitization) could not convince new investors to buy their products, so loan refinancing activity was very difficult. This resulted to bankruptcies of companies, and a huge drop in housing prices, thus, this led to bank failures. Thus, central banks made interventions, in order to rescue banks.

The financial crisis that began in the US in September 2007 was the result of many factors. For example, some authors believe that the beginning of the current economic crisis may be related to the low-interest rate policy adopted by the Federal Reserve and other central banks of G20s after the collapse of the stock market bubble in technology in 2001 (Hayford and Malliaris, 2010). On the other hand, Jawadi and Arouri (2011) argue that the economic crisis has its roots in many macroeconomic factors, which are closely linked with the strategies followed by FED.

The major issue in the function of the banking system is that in periods of economic growth banks provide a high percentage of their capital to loans, and also, they are also lending capital, either from the central bank of the interbank market in order to provide new loans. However, in order to gain a higher share in the loans market, banks do not always follow a strict risk management procedure, and they provide loans to parties which don't have the proper guarantees. So, these new loans result in higher demand for assets, creating the conditions of a bubble (Gourinchas and Obstfeld, 2012; Schularick and Taylor, 2012). As Carvallo \& Parliacci (2014) note, the bubble in the real estate was a result of this lending policy of banks. A further critic is that, as Bordo \& Jeanne (2002) note, while in periods of an economic growth banks are providing even higher loans, creating a bubble, in periods of a lower growth banks are decreasing to the lower levels the provision of new loans, creating the conditions of a recession. This is, in fact, a key issue of this study: the identification of other sources of financing for new enterprises, since Greek banks, after 2009, have dramatically decreased the provision of loans to enterprises.

\section{Entrepreneurship in Times of Financial Crisis}

\subsection{EU Policies Regarding Entrepreneurship}

Europe has been faced with a crisis, which led to some countries in recession, rising unemployment, increased share of the population at risk of poverty and social exclusion. At the same time, the European Union is losing ground to competing countries such as the US, Japan, etc., in a number of areas such as innovation. Against this background, European Commission had to develop a strategy that would increase economic activity, but would no longer have the same resultants with those of the past. Thus, for example, it was realized that is not enough for member countries to meet the aims of the Stability and Growth Pact, but should be set a number of other targets, which would allow the long-term and sustainable development of the European Union. Given, however, that the Member States can no longer have the same fiscal policy by borrowing and by having deficits in order to stimulate their economies, these new axes should 
have the aspect of innovation and creativity.

At the same time, it became clear that there should be one strategic plan to ensure that unemployment will decrease and there will be that safety net that will not allow the social exclusion of the most vulnerable population groups. Also, climate change is an important aspect of development. Therefore, the development should be done in a way that not only not incompatible, but enhances ecology. Based on these parameters, the strategy Europe 2020 program was designed. The Europe 2020 has set three priorities: 1) Smart growth understood as those based on knowledge and innovation, 2) Sustainable development, in which there are a less energy intensive and more ecological economy, and, 3) Comprehensive development, where the economy will have high employment, through which to achieve social and territorial cohesion. These three priorities have been defined by the following objectives: $75 \%$ of the population aged 20 64 should be employed, the $3 \%$ of EU GDP should be directed to research and development, the 20/20/20 objectives, referring to climate and energy, will be attained along with a $30 \%$ increase of reducing gas emissions, given the current conditions, the proportion of the early school leavers should be under $10 \%$ and $40 \%$ of the younger generation should be higher education graduates, it should have achieved a reduction of poverty by 20 million people. The key to the achievement of Europe 2020 is the involvement of each country strategy, which will be monitored with special reports and recommendations are given in each country to facilitate the achievement of objectives. Also, in cases where a country member records reduced response, there will be notice. The assessments of each country are projected to relate to the performance of countries both in terms of the Stability and Growth Pact and in terms of Europe 2020, a single evaluation framework.

Having set these priorities, the European Commission has focused on a series of initiatives that will be undertaken in order to have action. Thus, with respect to the priority of smart growth initiative arises as to facilitate the research funding, because in this way new ideas are converted into products. Also, the initiative for the "Digital Agenda for Europe", as it develops the access to high-speed internet, both households and businesses will have additional benefits, which would enable the promotion of knowledge and innovation. Also, as growth through knowledge and innovation passes through entrepreneurship, it has been the initiative to strengthen small and medium-sized enterprises. Of course, this initiative is a direct connection not only with the priority of smart growth and inclusive growth, and this is because, with the creation of new food companies, jobs are created. Thus, it appears that the priorities are complementary and interdependent. Regarding the priority of sustainable development by taking the initiative of efficient use of resources, which provides support for the transition of the member states of the European Union into a low carbon economy and to adopt a series of actions concerning transport, support for renewable energies and energy efficiency. On the third priority, the initiative provided for the development of new skills and jobs, through which, people outside the labor market will acquire new skills through lifelong learning programs. Thus, drastically limited their exclusion from the labor market, and then significantly restricted and their social exclusion. Moreover, the acquisition of new skills supported the goal of smart growth. Simultaneously with lifelong learning, it is important to the adaptation of the labor market with more mobility and flexibility. In the last 15 years entrepreneurship internationally recognized as a key factor for economic growth. The European Union considers small businesses the key source of business dynamism and innovation and looks forward in particular to them to play their role in making Europe the most competitive and dynamic economy.

Entrepreneurship has many benefits for societies, the main wealth creation and reducing unemployment rates (Huggins \& Williams, 2011). Given that local communities provide the conditions and resources to develop a business, entrepreneurship is directly linked to local economic development (Ribeiro-Soriano\& Galindo-Martn, 2012; Verdujin \& Essers, 2013). Huggins \& Williams (2011) point out that there must be a supportive climate to encourage entrepreneurship on the part of the regions, to attract investment and capable human resources, but also to hold existing businesses. For creating this climate and business promotion policies, very important is the State contribution. This is because both the institutional and regulatory framework on the part of state bodies may either favor or hinder entrepreneurship and other entrepreneurship can contribute to changing the institutional framework (Kalantaridis \& Fletcher, 2012). These policies may involve the creation of new enterprises, especially in nonadvantageous areas, policies relating to funding issues and finding funds from existing operations, policies aimed at developing a more favorable regulatory environment for businesses by reducing corruption and tax deductions business and policies that encourage cooperation between regions (Huggins and Williams, 2011; Méntez-Picazo et al., 2012; Smallbone \& Welter, 2012). Finally, they should be mentioned and policies that encourage entrepreneurship by young people (Lamotte \& Colovic, 2013), the various national minorities (Verdujin \& Essers, 2013) and women (Verheul et al., 2006).

The EU policy on entrepreneurship is defined by three main objectives: a) increase the number of people involved in business, b) creating a framework which contributes to the efficiency of entrepreneurship and strengthening development impacts, c) creating a social culture which promotes entrepreneurship.

In the Green Paper on Entrepreneurship, the European Union identifies ways in which to achieve each of these goals. These modes are: 1) enlargement of people involved in business, 2) To create a framework that will contribute to the efficiency of entrepreneurship and to enhance the development impact, 3) creating a social culture which promotes entrepreneurship. Additionally, in the "European Agenda for Entrepreneurship" in 2004 identified five 
objectives of the European Union for entrepreneurship which are: a) cultivating an entrepreneurial culture, b) increasing the number of entrepreneurs, c) preparation of entrepreneurs for growth and competitiveness, d) improving the flow of finance and e) creating a more friendly regulatory and administrative framework for SMEs.

\subsection{Sources of Entrepreneurship and New Ideas}

\subsubsection{Clusters}

Clusters are defined by the cooperation of producers, service providers, research and educational institutions, financial institutions and other private and public entities related through different types of connections. There is huge diversity among groups: they vary in their growth stage and during their life cycle. Some of these clusters are networks of SMEs, some are developed based on the most important large companies, while others have developed around universities (Drucker, 1985). The relatively low innovation performance in Europe was the subject of many recent analyses and reports. It is an important issue for Europe because innovation is becoming the driving force of prosperity and growth, as countries attain higher levels of income. While the poorest countries have the potential to grow by investing in production capacity and the adoption of technology developed in other countries, the richer countries should muster their productivity for the introduction of new products, services, or efficient customer service ways to maintain their prosperity. To this end, collaborative groups can play a key role.

Innovation is characterized as an open process, which cooperates in complex ways many different factors, such as companies, customers, investors, universities and other organizations. The traditional linear model of entrepreneurship and innovation, with clearly defined roles for basic research in universities and applied research in a research and development company is no longer effective. Entrepreneurship and Innovation can take advantage of the geographical proximity, which facilitates the movement of knowledge and unplanned interactions that are critical parts of the innovation process. This is one of the reasons why innovation occurs at the local level, while the benefits are spread more widely through improved productivity. Clusters that may incorporate the features of the modern innovation process: can be considered as innovation systems on a small scale. Successful clusters undertake all activities required to deliver a great value to customers. At the same time, they go beyond traditional definitions of industries and construction in relation to the services and may even arise where the companies' locations are not determined by the location of markets or natural resources. The specific nature, including their territorial coverage, varies depending on the technology, market conditions and other factors affecting the geographical area and the relative strength of social ties (Praszkier \& Nowak, 2011).

Economic activity within a particular cluster tends to be more concentrated in some areas. Individual regions more specialized in specific, different clusters, and more interlinked. This allows the overall economic activity to be distributed relatively evenly in different areas, even if individual regions change specialization (Kiss, Danis, \& Cavusgil, 2012). Areas without specialization are facing the risk of being left behind on economic development. Therefore, it must be provided in all regions of the conditions and opportunities for successful participation in this process. Clusters can contribute to the prosperity of a region, but not the only explanation for competitive advantages. The presence and depth of the teams in a regional economy is one aspect of the overall business environment facing enterprises in the region. Also, other factors and circumstances must be considered, such as the Competitiveness and demand conditions. Clusters are most likely to emerge, thrive and survive when these conditions maintain high productivity and innovation (Kiss, Danis, \& Cavusgil, 2012). Clusters and regional specialization empirically associated with higher levels of innovation and prosperity. According to the European Cluster Observatory, about $30 \%$ to $40 \%$ of total employment located in sectors concentrated or formed at the regional level. The regions with the highest share of employment in industries that are part of major clusters are generally more robust. Since employment reflects the activities in many industries belonging to such clusters, prosperity grows longer. The location in cluster groups linked through common industries or groups operating in neighboring areas provides additional benefits. While there are many factors other than the formations, which may impact on prosperity, the data provide clear evidence that clusters largely associated with prosperity and, therefore, that there is a need to consider the clusters as central part of any economic strategy. A more extensive analysis of these factors is being carried out by the European Cluster Observatory, based on recent academic work on the subject (Kiss et al., 2012; Dimitratos et al., 2012).

\subsubsection{Entrepreneurship Education}

Hansemark (1998) states that traditional education is simply marked as conversion of knowledge and skills, and entrepreneurship education, by contrast, is a model for changing behavior and motivation. Entrepreneurship and entrepreneurship education, besides the obvious advantages, such as promoting the business creation, also has a wider dynamic market (Hess, 2006). Two of the most important conditions for success when starting a new business is the desire or incorporation capacity. Entrepreneurial mindset not only required during a classic entrepreneurial career, but is clearly in high demand regardless of labor relations. Entrepreneurship education seeks to teach people, especially young people, responsibility and courage. Enterprising individuals who become entrepreneurs or entrepreneurial thinkers contribute to economic development and creating sustainable communities (Hess, 2006). As Ahmad and Hofmann (2012) note that the activities of entrepreneurship education need: "dedicated entrepreneurship centers, internships, teacher and advisor education, and research are necessary for success. Policy initiatives should ensure the 
supply and quality of entrepreneurship education" (Ahmad and Hoffmann, 2012, p. 27).

According to the European Commission on fostering entrepreneurial mindsets through education and learning, entrepreneurship education can be defined as follows: Entrepreneurship refers to an individual's ability to turn ideas into action. It includes creativity, innovation and risk-taking, and the ability to plan and manage projects in order to achieve objectives. This supports the society as a whole and pushes employees to know the context of their work in order to be better able to seize opportunities. It also provides a foundation for entrepreneurs establishing a social or commercial activity (Szabo \& Herman, 2012). The consortium for entrepreneurship education (2008) states that entrepreneurship education not only involves teaching to running a business but also to encourage creative thinking and promote a strong sense of self-worth and empowerment. Through entrepreneurship education, students learn not only how to create businesses, but also much more. The core of the knowledge generated through entrepreneurship education includes (Hess, 2006): 1) Ability to recognize the opportunities presented, 2) Ability to pursue opportunities by creating new ideas and acquire new resources, 3)Recommendation capability and a new business, 4) Creative and critical thinking ability.

According to Hoffmann et al. (2012), entrepreneurship education is a continuum, which involves the education regarding the business planning, the operational management, the knowledge about the capital formation and the sources of financing, etc. Given the proliferation of entrepreneurship education, it is necessary to set up a framework in this regard. Jameson (1984) proposed a framework of three categories, recognizing the roles that represent the various types of education. The first category deals primarily with creating awareness, and aims to inform students on issues related to the creation and operation of a business (from a theoretical perspective). The business units within enterprises and other subjects at the undergraduate or graduate level can also be included in this category (Hess, 2006).

The second category is more concerned with the training of candidate entrepreneurs in self-employment, to encourage the participants to establish and manage their own business. People are taught the practical skills needed for business management. The courses are often directed to prepare a business plan. Examples of this type of training in entrepreneurship is starting a business (Hess, 2006). The third category includes management training for established entrepreneurs and focuses on ensuring the expansion and development of business (Hess, 2006). Examples of these programs may be the business management and training in product development and marketing courses. This training provides the skills, knowledge and methodology to entrepreneurs in order to innovate and solve the problems which might occur. Garavan and O'Cinneide (1994) have adopted a broader view on the categorization of education and training in entrepreneurship, distinguishing between business education and education and training for small business owners. The first is described as a business education that aims to empower learning conditions which favor the creation of new businesses, and the various theories concerning the nature of the characteristics required for successful entrepreneurship.

However, Garavan and O'Cinneide (1994) focused more on education and training for small business owners and have split this type of education into three categories, which appear to be associated with the personal development stage: (i) training in business awareness commonly found in secondary education, (ii) education and training in the area where they operate small business owners and (iii) the more specialized training designed to enable people to further develop their skills (Hess, 2006).

According to Moberg and Vestergaard (2012), a holistic model of entrepreneurship education begins with the inspiration and information, as well as the continuous training of the trainers, since entrepreneurship is a dynamic process and not a static activity. The main objectives of entrepreneurship education are the development of entrepreneurship encouraging an attitude of autonomy using appropriate learning processes. Education and training programs in entrepreneurship directly aimed at promoting entrepreneurship itself (mostly targeted at entrepreneurs, whose objective is the search development opportunities in business). Research on entrepreneurship education focus mainly on the university level (Thorp \& Goldstein, 2010; Morris, Kuratko, \& Cornwall, 2013), or secondary level (Zhao, 2012). It is imperative to understand that entrepreneurship and business education at a young age, is not only for existing and new businesses. With more education and encouragement, young people should be able to realize their business aspirations. This effect will increase the economic development of communities and open new employment and career opportunities, regardless of economic circumstances (Drucker, 1985). Despite the fact that not all of people will be entrepreneurs, students and society benefit when people have a solid education, which gives them the business knowledge and skills during their life. So, according to Hofmann et al. (2012), an holistic framework for measuring entrepreneurship education includes the identification of inputs in the national level (human resources, capital, natural resources), the activity (business sectors, level of the companies), and the outcome (level of economic activity, level of value-added activities), regarding the effects on two levels: the user-oriented effect -the effects of entrepreneurship education to the entrepreneur himselfand the effects of the entrepreneurship education in society.

\subsection{Funding the New Idea}

The funding of the new idea is the key element for the establishment of companies. Without capital, the enterprises cannot survive and cannot ensure their growth. A major issue in this part of the analysis has to do with the sources of funding. The success rates of banking loans -that is, the number of the approved loans by the total number of loan 
requests- have been decreased during the crisis (Bamps and Schmiemann, 2012) as most of the banks, in periods of recession, are decreasing their loans provision.

\subsubsection{Funding from Banks}

The Bank loans are now the most common way in which businesses resort to find financing. Banks offer two broad categories of loans to firms: The working capital loans and long-term loans.

I. Commercial loans. Banks offer complete packages to meet SME liquidity needs. Such products are open or revolving loans and overdrafts. By open loans banks give a credit line to their client as that can be borrowed. The borrower can if he wants to pay part or all of the debt and may be refinanced when in need as the limit has been reached, without the need to return to this period the capital employed. There are banks that finance working capital as much as $100 \%$ of the company's turnover and other where this figure does not exceed $50 \%$ of the turnover (Padmalatha and Justin, 2010).

II. Property loans (Casu et al., 2006)

The commercial loans can finance up to $100 \%$ of the value of the property and their duration ranges from 3 to 30 years depending on the bank and the client, with interest rates usually variable, but in some cases, they can have fixed interest rate. For young entrepreneurs banks usually provide a grace period of up to two years, during which young entrepreneurs are required to pay only the interest or smaller payments.

III. Loans for purchase of fixed assets (Casu et al., 2006)

Loans of this kind are granted for the purchase of fixed equipment (furniture, machines, etc.). The repayment period of these loans reaches 15 years at an interest rate which is usually variable. The funding will cover the entire market investment of the fixed assets and disbursement can be either single or gradually depending on market trends.

One of the biggest problems faced by Greek companies is the liquidity provided by banks. From the beginning of the crisis to date, loans to companies have shrunk mainly due to two reasons: 1) The lack of bank access to the interbank market and 2) The increase in non-performing loans and credit risk

In addition to the practical difficulty of bank loans, it should be noted that most of the times, for business loans there is a requirement of collaterals, which makes it difficult $t$ for businesses to borrow in order to buy the necessary equipment and infrastructure. The level of the guarantees banks require in order to provide a loan has increased during the crisis, making even more difficult for enterprises to ask for a loan (Bamps and Schmiemann, 2012).

\subsubsection{Funding from the European Union and Government}

To provide an efficient and sustainable use of Structural and Cohesion Fund, various new tools and initiatives created. Sound financial management of the instruments of cohesion policy can contribute to increasing public investment. To achieve this, the European Commission adopted some tools that help Member States and regions together with the
European Investment Bank, the European Bank for Reconstruction and Development (EBRD) and the Council of Europe Development Bank (CEB) to implement various sources of financing. The JEREMIE initiative (Joint European Resources for Micro to Medium Enterprises - Joint European Resources for Micro to Medium Enterprises) allows the EU Member States, through the National and Regional Managing Authorities, the opportunity to use part of the aid received from the EU Structural funds in order to strengthen corporate financing in the form of investments in equity, loans or guarantees to SMEs, via a recirculating holding Fund, which has umbrella fund, that includes several sub-funds. This initiative was developed by the European Commission and the European Investment Fund (EIF), which is a partnership of public and private sector with the tripartite shareholder structure to include the European Investment Bank (in percentage 61.9\%), the European Union, represented by the European Commission (by 30\%) and 25 financial institutions from 15 EU Member States, (8.1\%). The JEREMIE, due to its structure (umbrella fund), does not grant finance to SMEs directly, but through financial intermediaries, to whom this Fund offers financial products targeted at SMEs, such as guarantees, co-guarantees and counter-guarantees for shareholdings equity, (micro) loans, securitization, venture capital, co-invests with business angels, investment and technology transfer institutions. Intermediaries provide SMEs (who are the ultimate beneficiaries) loans and equity participation. Before signing the JEREMIE Funding Agreement between the EIF and national or regional authority of an EU Member State, the Portfolio Fund prepares the investment strategy. The national or regional contractor transfer to a bank account the JEREMIE funds and, finally, at the invitation of interest, financial intermediaries are being selected.

The JEREMIE is General Entrepreneurship loans that finance SMEs in Greece given by the cooperating banks (National Bank and Eurobank) and co-financed with funds from the European Regional Development Fund through the NSRF and own resources of partner banks. Businesses will receive JEREMIE loan will pay only interest for $50 \%$ of the loan contributed to the bank's equity, and the remaining 50\% of the loan that is contributed through the JEREMIE initiative is interest-free. Eligible for funding are investment projects and investments in working capital, both for purposes of creating a new business or expanding an existing business, but rather for purposes of development and expansion of business activities. These loans finance investment projects for the acquisition of tangible and intangible fixed assets, working capital allocated to the development and expansion of business activities, working capital allocated to create a new business or expanding an existing business. The loans can be of up to EUR 500,000, while each business can participate in the program more than once, provided that the total amount of loans to be granted will not exceed 500,000 euros. Interest will be paid for 50\% of the loan (the amount that is granted by the bank), and the remaining $50 \%$ of the loan is contributed by the JEREMIE 
initiative.

\subsubsection{Funding from Venture Capital, Private Equity and Hedge Funds}

The venture capital and Private Equity, are investment vehicles that purchase business shares in exchange for the acquisition of shares ranging from a small minority to the majority ownership of the company (Divakaran et al. 2014). Usually, investors hold these securities for a period of three to seven years, with the expectation of creating attractive returns, when exiting the investment. The financing of the operation of venture capital may be carried out at various stages of the business life. Thus, there may be funding the exploration stage of a business idea, up to the final stage of development of the business in order to meet the 1 isting requirements of a stock exchange (Cochrane 2005; Divakaran et al., 2014).

\subsubsection{Business 'Angels'}

Business angels are a form of business financing that has shown significant activity in the last ten years. As noted in the Ahmad and Hoffmann (2012) study "it is believed that total funding by business angels is several times greater than all other forms of private equity finance. Governments in many countries try to cultivate business angels by organizing networks and giving special investment tax incentives. Several countries have also tried to improve information flows between angels and potential entrepreneurs that otherwise tend to be informal" (Ahmad and Hoffmann, 2012, p. 26). An important aspect of business angels is the nonfinancial dimension of their contribution, as they often have a placement on the board of the company, providing their personal knowledge and contacts in the company and take initiatives. In a survey of 31 business angels in the UK, found that the greatest contribution of business angels was to advise the formulation of business strategy (Mason and Harrison 1996, as mentioned in Politis 2008). Despite the fact that the operation of a business angel is similar to that of venture capital and all types of financial institutions, there are three important differences (Coweney and Moore, 1998). First, business angels make their investment in an SME with less bureaucracy, since they do not usually ask for the details required in the other forms of financing. The key element in business angel investment is the personal relationship of the business angel with the entrepreneur. Second, the size of investment in most cases is less than the venture capital and therefore is a more accessible source of capital for new SMEs. Third, business angels are more tolerant to the business risk for two reasons. First, in many cases, business angels choose to support an investment initiative, driven mostly by intuition based on experience rather than relying on a comprehensive business plan with clearly formulated long-term business goals (Politis, 2008). Then, business angels are willing to get involved in the administration of enterprise offering, alongside capital, their experience in the organization and administration of the business, and risk management. Instead, the management of other financial institutions do not usually want to be involved in the daily management of the business and risk management and therefore prefer to invest where the risk is low and have guaranteed a return on capital (Coweney and Moore, 1998).

\subsection{Organizational and Strategic Management of New Companies}

Werther et al. (1995) argue that the organization is a system of coordination of human activities in order to achieve the stated objectives. The organization is structured in a dynamic way, as an open system, and governance of the organization can be improved by the involvement of external consultants in the decisions. A key element in the organization there is strategic planning, which has three stages: the corporate mission, the principles and values of the organization and the vision of the organization (Grant, 2010). The statement of business ethics is a priority over all other corporate structures because this determines the way in which business operates. Thus, the business ethics statement should made clear which are the stakeholders, how to ensure the coverage of stakeholder needs, what are the procedures of work and how processes are controlled so as to ensure their relevance. The company should have created an environment that covering not only the interests of major shareholders of the company, but as well, the interests of other shareholders and investors (financial integrity), employees, suppliers, customers, competition (fair competition), the state (tax authorities) and the environment (environmental standards) (Grant, 2010). Through such a declaration corporate responsibility and integrity, the management makes it clear to employees, regardless of the hierarchical scale, how to exercise their functions and defines the impact will be in violation phenomena of these ethical principles. The second stage of the strategic planning is setting the business goals, which transform the business vision into specific goals that will be achieved after analysis of the internal and external environment of the enterprise. The business goal setting gives an answers to what the organization has to achieve in order to realize its vision. (Kachru, 2006). A widely used methodology for setting goals is the SMART method, under which the business objectives should, as indicated by the acronym to be: Specific Measurable, Achievable, Realistic and Time-Related (Yocam \& Choi, 2010). The goals set can be quantitative, qualitative, or a combination of quantitative and qualitative data (Strack, 2004). Examples of targets are to increase market share, displacing competitors and improve competitiveness. The third step is the selection of actions to be followed by the company in order to achieve the objectives. At this stage, it is allocating resources and establishing mechanisms to implement and monitor implementation of the strategy (Kachru, 2006)

In order to make the choice of appropriate action, the company should take into account parameters relating to both the internal and external environment. All these actions constitute the strategy chosen by the company to operate in the industry and bring about the desired results. According to Porter (1996) strategy is to do different things from those of your competitors or do the same things in different ways, and 
according to Johnson \& Scholes (1999), strategy is the direction and scope of action of an enterprise in the long term, which achieves competitive advantage through resource provision, in a changing environment, to meet the expectations of shareholders and other stakeholders. The company selects the appropriate strategy in line with the vision, mission, strategic approach, industry, product, and the special characteristics it has (Grant, 2010). We can distinguish the main strategies in cost leadership, differentiation and niche markets (Hitt et al. 2011). The strategic planning involves the stage at which an organization sets its objectives, or else it is that process that examines how the organization develops strategic objectives and action plans to implement these goals (Grant, 2010). It is basically the development of a vision for the future of the organization and setting priorities, procedures and operations to achieve that vision. In this kind of programming, the emphasis is given on long-term goals and that is the main reason why strategic planning is a continuous process, since essentially refers to the performance of long-term value added (Lynch, 2006, p. 9). Strategic planning is exercised by the senior management level, as regards the overall course and strategy of an organization and contribute to the performance of the whole organism (Montana \& Charnov, 2000). For the proper schedule and implemetnation of the strategic plan, the organization should have previously made a research on the product, buyers, industry and competition (Aaker \& McLoughlin, 2010). When analyzing the customer and the product, there are a series of questions, such as who and why they need the product, under what conditions someone buys the product what are the buyers' criteria and what needs the product covers, (Aaker \& McLoughlin, 2010). Based on the analysis above, the company will choose the strategy that will enable it to achieve its business objectives. The analysis is done at two levels: at the level of the firm macro environment (external environment) and the level of the microenvironment (internal environment) (Rummler \& Ramias, 2010).

An important analytical tool is the PEST analysis (political, economic, social, technological analysis). In this analysis, the company analyses the parameters of the external environment (macro-environment of the company), grouped into four levels: the political, economic, social and technological environment. This analysis is important because every company defines and shapes the strategic plan on the basis of the conditions prevailing in its broader environment (Williams \& Green, 1997). Subsequently, the company analyzes the micro-environment. One of the most prevalent ways for the micro-environment analysis is the SWOT analysis (strengths, weaknesses, opportunities, threats analysis) (Ferrell \& Hartline, 2014). During this analysis, the company records the points which have an advantage over its competitors (strengths), weaknesses against the competition), opportunities which can be exploited and risks - threats that may occur and impede the attainment of these objectives. Through SWOT analysis, the organization is able to record and analyze the elements that may determine its decisions
(Botten, 2009). All of the above elements are the key procedures in order to analyze both the market and the company, so that the organization could have long-term success.

\section{Research Methodology}

\subsection{Empirical Study}

The method chosen for the purpose of this research is an empirical research through the distribution of a questionnaire. This approach was chosen because it assists the investigation of a phenomenon by the views of its own interested parties (Muijs, 2010). In our case the interested parties are the enterprises which have been established in Greece after 2009. This method assists to explore the opinions, attitudes and behavior of subjects in research (Clark - Carter, 2004), enables statistical processing of data in order to quantify the respondents' views on the issue under consideration (Gray, 2014, Dawson, 2009). and needs less time than conducting qualitative research, while providing a greater level of impartiality and objectivity of the researcher in relation to the qualitative research, which is characterized by a high level of bias (Johnson and Christensen, 2008).

\subsection{The Questionnaire}

For the purpose of this study, as a research tool was used a questionnaire. The questionnaire is a tool that facilitates the objectivity of the research as it can assess the answers of the participants (Oppenheim, 1992). This methodological tool was chosen because it has the following advantages (Wilson and McLean, 1994): a) it is easy to be distributed to a large number of participants at the same time and in different geographical areas. In addition, the questionnaire allows the statistical analysis of the responses of participants and therefore the quantification of their views This is achieved through the use of open-close questions. Structured, and, open-close questions are useful as they can produce responses that can be handled and can be analyzed through statistical analysis (Oppenheim, 1992). Therefore, the above type of questions were used because they can more easily consolidate, undergo statistical processing, but also to interpret and quantify the production of results.

\subsection{Structure of the Questionnaire}

Question 1, 2, 3 and 4 cover the research questions of motives and incentives of entrepreneurship. One factor of entrepreneurship, as mentioned in the literature review, has to do with whether the person has previous entrepreneurship experience since previous experience has a positive influence to establish a new company again (Dyke et al., 1992). Even a previous entrepreneurship failure is a positive driver for the enterpneeur since he/she believes that the failure was in fact a lesson, so he/she will know better what to avoid, how to deal with risk and make better decisions (Politis \& Gabrielsson (2009). Also, sector experience, according to literature, has a positive result in someone's choice to establish a new 
company (Taylor and Thorpe, 2004). The entrepreneurship and sector experience is being covered by questions 1,2 and 3. The research question about the factors for the establishment of a company is being covered by question 4 . The research question regarding the identification of the main sources of new businesses financing is being covered by question 5. The research question of the entrepreneurs' preparation as indicated by the existence of a business plan is being covered by question 6 . Question 7 is regarding the research question of the institutional environment (clusters, universities, government agencies) in the concept of the business idea, Question 8 covers the research question of the examination of the factors which are connected to the establishment of companies. Question 9 examines the research question of the determination of the degree of adoption of forms of financing. Question 10 identifies the research question of whether the new entrepreneurs consider the crisis as a threat or as an opportunity.

\subsection{The Sample}

The two issues regarding a sample survey are access to the sample and its size (Gray, 2014). Regarding access, the researcher made a research on the chambers of Athens, Thessaloniki, internet and personal knowledge in order to identify the enterprises established after 2009. The questionnaire had been sending to 104 enterprises, of which 52 replied. Regarding the sample size in quantitative research, there are multiple opinions. For example, Fox et al. (2009) point out that it should consist of more than 40 subjects, while other researchers (e.g., Dawson, 2009) do not mention a specific number of participants. However, in order to ensure the further reliability of this survey, the sample consists of 49 companies, covering the requirement of Fox et al. (2009) for a sample of more than 40 participants.

\section{Results of the Primary Research}

Year of establishment

Regarding the year of establishment, in 2009, the first year of the financial crisis in Greece, fourteen (14) companies have been established. In 2010, the year where Greece had adopted the program of the Troika, 12 companies were established. After 2010, there was a decline of new companies. In 2011, eight (8), in 2012 Six (6), in 2013 four (4) companies and in 2014, five (5) companies were established. Totally 49 companies from 2009-2014. Regarding the business sector, the vast majority, 42 out of 49 companies are in the service sector $(85.7 \%), 6$ companies are in the manufacturing sector $(12.2 \%)$ and one company is in the energy sector, producing electric power through photovoltaic panels. Regarding the companies' legal form, 19 companies are private property companies (38.8\%), 15 companies are Limited Liability Companies (30.6\%), while six companies are limited partnership and six companies general partnership. There are only 3 SAs. While there are no private capital companies, nor cooperatives. Regarding previous experience, the majority of entrepreneurs do not have neither a previous entrepreneurship experience (79.6\%), nor a previous sector experience $(61.2 \%)$.

None of the entrepreneurs of private companies and general partnership companies had an entrepreneurship experience, while the $100 \%$ of the entrepreneurs of SAs had a previous entrepreneurship experience. For the entrepreneurs of LLCs and limited partnerships, half of them had a previous entrepreneurship experience. Regarding sector experience, all of SAs entrepreneurs and the majority of LLCs had previous sector experience, while for sole proprietorship and general partnership, the majority do not have a previous sector experience (Figure 1,2)

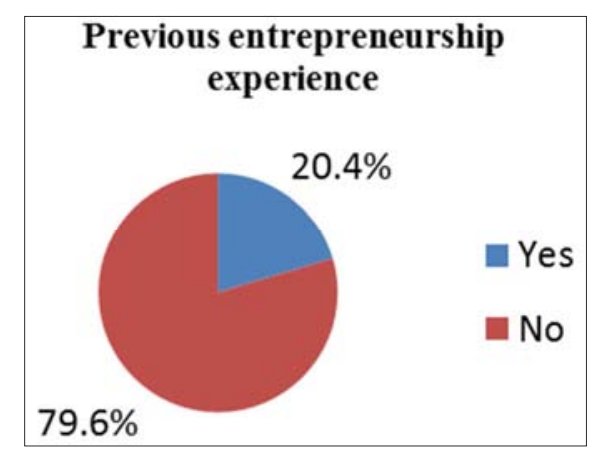

Figure 1. Previous entrepreneurship experience.

\section{Previous sector experience}

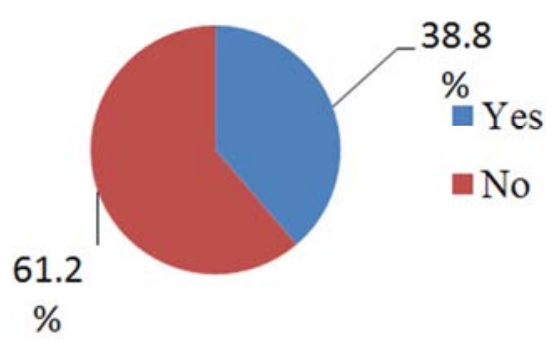

Figure 2. Previous sector experience.

Regarding previous activity, 20 out of 49 entrepreneurs were employees $(40.8 \%), 8$ were unemployed $(16.3 \%), 7$ were part-time employees $(14.3 \%), 6$ were entrepreneurs $(12.2 \%), 5$ were members of the family business $(10.1 \%)$ and 3 were self-employed (6.1\%) (Figure 3).

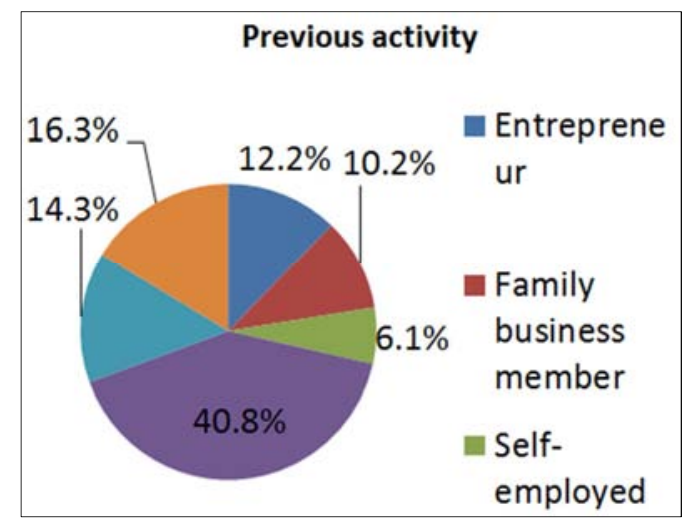

Figure 3. Previous activities. 
Regarding the previous activity, 4 of the entrepreneurs had a previous sector experience and 2 decided to establish the new company in a sector which had no experience. Most of the employees (12 out of 20) as well, decided to have a business activity in a sector not relative to the one they were working. Part time employees and unemployed had, as well, no previous experience of the sector. The vast majority of family business members decided to establish a company in a sector similar to the one they were working for. One of the main objectives of the study is to identify the key motive of entrepreneurs to establish their business.

The findings are as follows: $30.6 \%$ (15 companies) established the company out of necessity since there was no other option of a source of income. 26.5\% (13 companies) established in order to materialize their business idea. $22.4 \%$ (11 companies) established the company in order to have a permanent job.12.2\% (6 companies) established the company in order to exploit a business opportunity, $8.2 \%$ (4 companies) established the company in order to improve their income Figure 4).

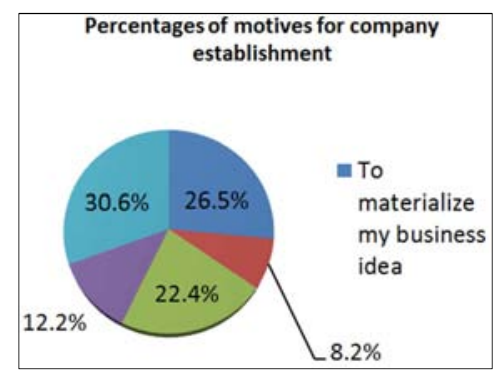

Figure 4. Motives for company establishment.

Another main objective of the study is the identification of the main sources of financing of the new businesses. There are multiple sources of financing which can be used, which can be used in combination.

The results show that: 55.1\% (27 companies) used own savings, $46.9 \%$ (23 companies) used family and friends' capital, $32.7 \%$ (16 companies) have been financed through the European Union and government programs, 20.4\% (10 companies) have been financed through bank loans, $2 \%$ ( 1 company) has been financed through venture capital / private equity, No company has been financed through business 'angels' (Table 1)

Table 1. Sources of capital.

\begin{tabular}{lllll}
\hline Own savings & $\begin{array}{l}\text { Friends / } \\
\text { Family }\end{array}$ & Bank loan & $\begin{array}{l}\text { European Union / Government } \\
\text { Funding Program }\end{array}$ & $\begin{array}{l}\text { Business angels } \\
\text { Equity }\end{array}$ \\
\hline 27 & 23 & 10 & 16 & 0 \\
\hline
\end{tabular}

Regarding business plan, 28 companies had not a business plan, while 21 companies had developed a business plan. Also, a major issue of entrepreneurship has to do with the sources of a business idea. Of course, an entrepreneur can use various sources, both personal and institutional, by combining information, know-how and data. The results show that most entrepreneurs, as key sources of business ideas, they use their family and friends (46.94\%), experience of their previous job $(34.69 \%$ and they are making a personal research $(30.61 \%)$. Regarding the degree of institutional environment (clusters, universities, government agencies) in the concept of the business idea, the results show that $20.41 \%$ are using the universities/colleges as sources of business ideas and $10.2 \%$ are using public organizations. Only $2.04 \%$ (one company) has used investors as a source of the business idea, while no company has used clusters. A major issue of entrepreneurship has to do with the factors which can help a person decide to create his/her own business, or, on the other hand, can be an obstacle to entrepreneurship. The results are as follows: The level of the tax rate is the key factor regarding a company's establishment. The second factor, in raking, is the availability of capital. Factor number three is the bureaucracy. The complexity of the taxation system is $4^{\text {th }}$ in ranking. The support of family and friends has the $5^{\text {th }}$ position. The expansion possibilities have the $6^{\text {th }}$ position.
The labor legislation is $7^{\text {th }}$ in ranking. Availability of human resources has the $8^{\text {th }}$ position. Information about the economy/sector/competition has the $9^{\text {th }}$ ranking. Entrepreneurship education is the last in ranking.

Regarding the ranking of sources of business financing, the results are as follows: Own savings/family/friends are appreciated as the most important source of business financing (99.2\%). Availability of bank lending is being recognized as the second most important source (66.3\%). Availability of European Union / Government funding programs is being recognized as the third most important source of financing (62.8\%). Business angels $(21.4 \%)$ and Venture Capital / Private Equity (17.9\%) are the lower appreciated sources of business funding.

The last question of the survey has to do with the determination of whether the new entrepreneurs consider the crisis as a threat or as an opportunity. About 31 entrepreneurs, which is the $63.3 \%$ believe that the crisis is an opportunity, while 18 entrepreneurs $(36.7 \%)$ believe that the crisis is a threat.

The perception of the crisis is not common among all of the participants. One variation regarding the perception of the crisis is among the participants according to their main motive of company's establishment (Table 2).

Table 2. Perception of the crisis per main motive of company's establishment.

\begin{tabular}{llllll}
\hline & $\begin{array}{l}\text { Income } \\
\text { improvement }\end{array}$ & Permanent job & $\begin{array}{l}\text { Exploit a business } \\
\text { opportunity }\end{array}$ & $\begin{array}{l}\text { Economic } \\
\text { necessity }\end{array}$ & $\begin{array}{l}\text { Materialization of business } \\
\text { idea }\end{array}$ \\
\hline Opportunity & 2 & 6 & 6 & 4 & 13 \\
Threat & 2 & 5 & 0 & 11 & 0 \\
\hline
\end{tabular}


As noted, the entrepreneurs who had, as their main motive, the materialization of their business idea, as well as to exploit a business opportunity, are, by $100 \%$, the perception of the crisis as an opportunity. On the other hand, the vast majority of entrepreneurs who created their companies out of necessity, ve the perception of crisis as a threat, rather than an opportunity.

\section{Discussion, Limitations of the Study and Future Research Directions}

The main purpose of the current study is the identification of the factors which affect the decision of setting up new businesses in Greece, as well as identifying the factors associated with entrepreneurship, in a changing economic environment: Austerity measures have been adopted by the government, the banking sector has fewer resources to provide liquidity, consumption is decreasing, while unemployment remains at high levels. Entrepreneurship, both as a concept and as a practice, is a way to boost economic activity, in a long-term horizon and in a sustainable way. Entrepreneurship is directly connected to innovation, as well as to the development and promotion of country's competitive advantage. On the other hand, entrepreneurship has, neither as a concept nor as practice, a unique form. People can establish a new company not because of a business idea or because of an analysis of the environment, but out of necessity. This way of entrepreneurship, although it solves some problems regarding the employment and is a source of potential income, can not guarantee growth in a stable and long-term growth. In the current analysis, the major findings show that new companies, established after the beginning of the crisis, is in the services, which is a nontradable sector, so it is extremely hard to improve the country's competitiveness. Entrepreneurs, in a great percentage, tend to rely on friends and family, not just as a source of capital, but also as a source of business ideas. They are underestimating the role of institutions, such as universities and clusters on the formation of new business ideas. As the primary research shows, only a few entrepreneurs are making a business plan, and, at the same time, they don't recognize the role of venture capitals and private equities as major sources of capital providers: instead, they overestimate the role of own savings, as well as the savings of family and friends.

Many new businesses have been established out of need, by unemployed or part-time employed people, who could not exploit a business opportunity they might prefer more. In that sense, they do not feel the need to have a business plan, not to actively search for capital. The main sources of capital are the friends and family, plus some help from the EU and government programs. Although most companies are recognizing the role of banks regarding liquidity provision, they do not have a business plan, which is essential in order to get a banking loan.
A major issue of the study has to do with the funding capital of the new company. The analysis shows that most enterprises ignore the existence and the role of private equity, hedge funds and business angels. The study of Bamps and Schmiemann (2012) shows that there is a decrease of banking loans and new forms of financing, such as private equities and business angels are gaining share to business financing in Europe. Also, Minitti and Levesque (2008) note, at the beginning of the crisis, that hedge funds and private equities are replacing banks as providers of capital. This study shows that this trend has not been followed in Greece, something that should change if companies want to have a more flexible source of capital. There is a combination of factors which sets on overall image of entrepreneurship environment in Greece as one of the "necessity entrepreneurship": Many companies have the legal form of "Sole Proprietorship", which is an indication of low capital needs. As the main source of capital are being recognized the personal savings, accompanied by friends' and family's savings. Many entrepreneurs took their decision because they were unemployed. Many entrepreneurs do not have a business plan. Most entrepreneurs are underestimating the role of entrepreneurship education, setting it as last in the ranking of the important factors of Entrepreneurship. The factor of the possibilities of expansion has a low ranking among entrepreneurs.

Although Greece has the second higher ranking among EU countries regarding the preference of self-employment, the current analysis shows that a big part of the self-employment motive is due to the need of entrepreneurship and not due to entrepreneurship as opportunity. Another key finding of the study is the lack of the involvement of the institutional environment, such as clusters and entrepreneurship education, to the establishment of new companies. A series of analyses (Bowen and De Clercq, 2008; European Commission, 2008; Mayjhew et al., 2012; Braunerhjelm and Henrekson, 2013; De Hoyos-Ruperto et al., 2013) show that the institutional environment, education and the networking of companies through clusters are very important elements for the successful entrepreneurship; instead, in Greece their role has not been acknowledged by entrepreneurs. On the other hand, there are clear signals that Greek entrepreneurs can be the decisive factor for the country's progress and growth: in the midst of the crisis, people are establishing companies, with all and everything they have. They have to fight against bureaucracy, the level of tax rate and the complexity of the tax system, with the lack of an institutional information regarding the economy, sectors and the global competition. They have to fight with the decreasing liquidity of the banking system. However, instead of giving up, many are establishing new companies.

\section{Conclusion}

According to Ireland et al. (2003) "Entrepreneurship is a context-dependent social process through which individuals 
and teams create wealth by bringing together unique packages of resources to exploit marketplace opportunities" (Ireland et al., 2003). In the case of Greece, instead of exploiting opportunities, many entrepreneurs are establishing companies because they have no other alternative, which is an indication of risk regarding the survival and the growth of these companies. What can be concluded from the current research is that Greek entrepreneurs have to take measures in order to keep pace with the needs of the times: in order companies to be established, they need ideas that will come from the institutional environment, such as the universities and clusters. They need capital, which can come from investors when there is a good business plan. They need entrepreneurs to be trained. Moreover, last but not least, they need State to be a supporter and not an obstacle.

\section{Limitations}

The basic limitations of the research were the number of responding enterprises in the questionnaire and the restriction of the research to a few geographical regions. The sample size could be larger, focusing mainly on the larger and more profitable businesses. The research was limited in the areas of Athens, Thessaloniki and Imathia, while it would be useful to include more areas in order to reveal the areas with the lowest rate of new business creation. This could be very useful for the development of the entrepreneurship in these regions.

\section{Suggestions for Further Research}

Some improvements and expansions could be made to this study. There could be a research about the links of the entrepreneurship and the general principles of management. Knowledge of marketing, human resource management, strategic management would be useful and necessary for the development of entrepreneurship in Greece? Another issue for further research could be the intention of the business for further investment during the economic crisis, examining which factors would affect this.

\section{References}

[1] Aaker, D. A. and McLoughlin, D., 2010. Strategic market management: global perspectives. Chichester: John Wiley and Sons.

[2] Agrawal, A. and Knoeber, C. R., 1996. Firm performance and mechanisms to control agency problems between managers and shareholders. The Journal of Financial and Quantitative Analysis, 31 (3): 377-397.

[3] Ahmad, N. and Hoffmann, A., 2012. A framework for Addressing and Measuring Entrepreneurship. In Eurostat (Ed.), Entrepreneurship determinants: culture and capabilities. Brussels: Eurostat.

[4] Ahmad, N. and Seymour, R. G., 2012. Defining Entrepreneurial Activity: Definitions Supporting Frameworks for Data Collection. In Eurostat (Ed.), Entrepreneurship determinants: culture and capabilities. Brussels: Eurostat.

[5] Baker, H. K., Filbeck, G. and Kiymaz, H., 2015. Private equity: an overview. In H. K. Baker, G. Filbeck and H. Kiymaz (Eds.), Private Equity: Opportunities and Risks, Oxford: Oxford University Press, 3-15.

[6] Bamps, P. and Schmiemann, M., 2012. Access to Finance by Small Firms in the EU: A Comparison of Situations in 2007 with 2010 and an Outlook into the Future. In Eurostat (Ed.), Entrepreneurship determinants: culture and capabilities. Brussels: Eurostat.

[7] Bordo, M. D. and Jeanne, O., 2002. Monetary policy and asset prices: does 'benign neglect' make sense? International Finance, 5 (2): 139-164.

[8] Botten, N. (2009). Enterprise strategy. Oxford: CIMA Publishing.

[9] Bowen, H. P. and De Clercq, D., 2008. Institutional Context and the Allocation of Entrepreneurial Effort. Journal of International Business Studies, 39 (4): 747-767.

[10] Braunerhjelm, P. and Henrekson, M., 2013. Entrepreneurship, institutions, and economic dynamism: lessons from a comparison of the United States and Sweden. Industrial and Corporate Change, 22 (1): 107-130.

[11] Brickley, J., Lease, R., and Smith, C., 1988. Ownership Structure and Voting on Antitakeover Amendments. Journal of Financial Economics, 20: 267-292.

[12] Carvallo, O. and Pagliacci, C., 2014. Macroeconomic Shocks, Housing Market and Banks' Performance. Banco Central de Venezuela Working Paper No. 147.

[13] Casson, M. and Wadeson, N., 2007. Entrepreneurship and macroeconomic performance. Strategic Entrepreneurship Journal, 1: 239-262.

[14] Casu, B., Girardone, C. and Molyneux, P., 2006. Introduction to banking. Harlow: Financial Times Prentice Hall.

[15] CFACG (Committee on the Financial Aspects of Corporate Governance), 1992. The financial aspects of corporate governance. London: Gee Publishing.

[16] Chaston, I., 2010. Entrepreneurial management in small firms. London: Sage Publications.

[17] Clark - Carter, D., 2004. Quantitative psychological research. New York, NY: Psychology Press.

[18] Cochrane, J. H., 2005. The Risk and Return of Venture Capital. Journal of Financial Economics, 75 (1): 35-57.

[19] Coveney, P. and Moore, K., 1998. Business Angels: Guide to Better Financing Through the UK Informal Venture Capital Market. Hoboken, NJ: John Wiley \& Sons.

[20] Davidsson, P., 2004. Researching Entrepreneurship. New York, NY: Springer.

[21] Davies, P. L., 1997. Institutional investors as corporate monitors in the UK. In Hopt, K. J. and Wymeersch, E. (Eds.), Comparative corporate governance: essays and materials, Berlin: Walter de Gruytter \& Co.

[22] Dawson, C., 2009. Introduction to research methods: A Practical Guide for Anyone Undertaking a Research Project. Oxford: How to Books. 
[23] Dawson, C., 2009. Introduction to research methods: A Practical Guide for Anyone Undertaking a Research Project. Oxford: How to Books.

[24] De Hoyos-Ruperto, M., Romaguera, J. M., B. Carlsson, B. and Lyytinen, K., 2013. Networking: A Critical Success Factor for Entrepreneurship. American Journal of Management, 13 (2): $55-72$.

[25] Dimitratos, P., Plakoyiannaki, E., and Nakos, G., 2012. International entrepreneurial culture-Toward a comprehensive opportunity-based operationalization of international entrepreneurship. International Business Review, 21 (4): 708-721.

[26] Divakaran, S., McGinnis, P., and Shariff, M., 2014. Private Equity and Venture Capital in SMEs in Developing Countries. The Role for Technical Assistance. World Bank, Policy Research Working Paper 6827.

[27] Dodd, R., 2008. Consequences of Liberalizing Derivatives Markets. In: J. A. Ocampo and J. Stiglitz (Ed.), Capital Market Liberalization and Development. Oxford: Oxford University Press.

[28] Drucker, P., 1985. Innovation and Entrepreneurship. New York: Harper Business.

[29] Drucker, P., 2006. Innovation and Entrepreneurship. New York, NY: Harper Business.

[30] Dyke, L., Fischer, E. and Reuber, A., 1992. An inter-industry examination of the impact of owner experience on firm performance. Journal of Small Business Management, 30: 826.

[31] European Commission, 2003. Entrepreneurship in Europe. European Commission.

[32] European Commission, 2008. Entrepreneurship in Higher Education, Especially Within Non-Business Studies: Final Report of the Expert Group. Brussels: European Commission.

[33] FCIC (Financial Crisis Inquiry Commission), 2011. Final Report of the National Commission on the Causes of the Financial and Economic Crisis in the United States. Official Government Edition. Washington, D. C: FCIC.

[34] Ferreira, M. A. and Matos, P., 2008. The Colors of Investors' Money: The Role of Institutional Investors around the World. Journal of Financial Economics, 88: 499-533.

[35] Ferrell, O. C and Hartline, M., 2014. Marketing strategy. $6^{\text {th }}$ ed. Mason, $\mathrm{OH}$ : South-Western Cengage Learning.

[36] Filion, L. J., 2011. Defining the entrepreneur. In L.-P. Dana (Ed.), World Encyclopedia of Entrepreneurship. Cheltenham: Edward Elgar: 41-52.

[37] Fox, N., Hunn, A. and Mathers, N., 2009. Sampling and sample size calculation. Nottingham: The NIHR RDS for the East Midlands / Yorkshire / Humber.

[38] Freytag, A. and Thurik, R., 2009. Entrepreneurship and Culture. London: Springer.

[39] Gartner, W. B., 1988. "Who is an Entrepreneur" is the wrong question. American Small Business Journal, Spring, 11-31.

[40] Gatewood, E. J., Greene, P. G. and Thulin, P., 2014. Sweden and the United States: Differing Entrepreneurial Conditions Require Different Policies. In P. Braunerhjelm (Ed.), 20 Years of Entrepreneurship Research - From small business dynamics to entrepreneurial growth and societal prosperity. Stockholm: Swedish Entrepreneurship Forum.

[41] Gillan, S. L., and Starks, L. T., 2003. Corporate Governance, Corporate Ownership, and the Role of Institutional Investors: A Global Perspective. Weinberg Center for Corporate Governance Working Paper No. 2003-01.

[42] Gourinchas, P. and Obstfeld, M., 2012. Stories of the twentieth century for the twenty first. American Economic Journal: Macroeconomics, 4: 226-265.

[43] Grant, R. M., 2010. Contemporary Strategic Analysis. 7th ed. Chichester: John Wiley and Sons.

[44] Gray, D. E., 2014. Doing research in the real world. London: Sage.

[45] Greene, F., Mole, K., \& Storey, D., 2007. Three Decades of Enterprise Culture?: Entrepreneurship, Economic Regeneration and Public Policy. Palgrave Macmillan.

[46] Gualandri, E., Landi, A., Venturelli, V., 2009. Financial Crisis and New Dimensions of Liquidity Risk: Rethinking Prudential Regulation and Supervision. Journal of Money, Investment and Banking, 7(8): 25-42.

[47] Hess, F., 2006. Educational Entrepreneurship: Realities, Challenges, Possibilities. Harvard Educational Pub Group.

[48] Hess, F., 2008. The Future of Educational Entrepreneurship: Possibilities for School Reform. Harvard Education Press.

[49] Hirschman, A. O., 1970. Exit, voice, and loyalty: responses to decline in firms, organizations, and states. Cambridge, MA: Harvard University Press.

[50] Hitt, M., R. Ireland, R. D. and Hoskisson, R., 2015. Strategic Management: Concepts: Competitiveness and Globalization. $11^{\text {th }}$ ed. Stamford, CT: Cangage Learning.

[51] Huggins, R. and Williams, N., 2011. Entrepreneurship and regional competitiveness: The role and progression of policy. Entrepreneurship and Regional Development: An International Journal, 23(10): 907-932.

[52] Ireland, R D, M A Hitt, M. A. and Sirmon, D. G., 2003. A Model of Strategic Entrepreneurship: The Construct and its Dimensions. Journal of Management, 29(6): 963-989.

[53] Jennings, D. F., 1994. Multiple Perspectives of Entrepreneurship. Mason. OH: South Western Publishing.

[54] Johnson, B. and Christensen, L., 2008. Educational research: Quantitative, qualitative, and mixed approaches. Thousand Oaks, CA: Sage.

[55] Johnson, G., Scholes, K., and Whittington, R., 2005. Exploring corporate strategy: text and cases $\left(7^{\text {th }} \mathrm{ed}\right)$. Essex: Financial Times Prentice Hall.

[56] Johnson, G. and Scholes, K., 1999. Exploring corporate strategy. 5th edition. London: Prentice Hall Europe.

[57] Kachru, U., 2006. Strategic management: concepts and cases. New Dehli: Excel Books.

[58] Kalantaridis, C. and Fletcher, D., 2012. Entrepreneurship and institutional change: A research agenda. Entrepreneurship and Regional Development: An International Journal, 24(3-4): 199-214. 
[59] Kirzner, I., 1973. Competition and entrepreneurship. Chicago: The University of Chicago Press.

[60] Kirzner, I., 2013. Competition and Entrepreneurship (The Collected Works of Israel M. Kirzner). Liberty Fund Inc.

[61] Kiss, A., Danis, W., and Cavusgil, T., 2012. International entrepreneurship research in emerging economies: A critical review and research agenda. Journal of Business Venturing, 27 (2): 266-290.

[62] Kuratko, D. F., 2009. Entrepreneurship: theory, process, and practice. $8^{\text {th }}$ ed. Mason, OH: South-Western Cengage Learning.

[63] Lumpkin, G. T., and Dess, G. G., 1996. Clarifying the entrepreneurial orientation construct and linking it to performance. Academy of Management Review, 21 (1): 135172.

[64] Lynch, R., 2006. Corporate Strategy. 4th ed., Essex, UK Financial Times Prentice Hall.

[65] Mayhew, M. J., Simonoff, J. S., Baumol, W. J., Wiesenfeld, B. M. and Klein, M. W., 2012. Exploring Innovative Entrepreneurship and Its Ties to Higher Educational Experiences. Research in Higher Education, 53 (8): 831-859.

[66] McClelland, D. C., 1961. The achieving society. Princeton, NJ: Van Nostrand.

[67] Méntez-Picazo, M. T., Galingo-Matrn, M., RIbeiro-Sobriano, D., 2012. Governance, entrepreneurship and economic growth. Entrepreneurship and Regional Development: An International Journal, 24(9-10): 865-877.

[68] Merrouche, O. and Nier, E., 2010. What caused the global financial crisis? Evidence on the drivers of Financial Imbalances 1999 - 2007. IMF Working Paper No. WP/10/265.

[69] Minniti, M., and Levesque, M., 2008. Recent development in the economics of entrepreneurship. Journal of Business Venturing, 23: 603-612.

[70] Mitchell, R. K., Busenitz, L., Lant, T., McDougall, P. P., Morse, E. A. and Smith, B., 2002. Toward a theory of entrepreneurial cognition: Rethinking the people side of entrepreneurship research. Entrepreneurship Theory \& Practice, 27: 93-104.

[71] Montana, P. J., and Charnov, B. H., 2000. Management. $3^{\text {rd }}$ ed. Hauppauge, NY: Barron's Educational Series.

[72] Morris, M., Kuratko, D., andCornwall, J., 2013. Entrepreneurship Programs and the Modern University. Edward Elgar Pub.

[73] Muijs, D., 2004. Doing Quantitative Research in Education. London: Sage.

[74] Muthaih, K. and Venkatesh, S., 2012. A study on the barriers affecting the growth of small and medium enterprises in India. International Journal of Research in Computer Application Management, 2(1): 77-81.

[75] OECD, 2011. The role of institutional investors in promoting good corporate governance. Paris: OECD.

[76] Oppenheim, A. N., 1992. Questionnaire Design, Interviewing and Attitude Measurement. Continuum, London.

[77] Padmalatha, S. and Justin, P., 2010. Management of banking and financial services. $2^{\text {nd }}$ ed. Chandigarh: Pearson Education.

[78] Politis, D. and Gabrielsson, J., 2009. Entrepreneurs' attitudes towards failure. International Journal of Entrepreneurial Behaviour \& Research, 15 (4): 364-383.

[79] Porter, M., 1996. What is a strategy? Harvard Business Review, November-December, 61-78.

[80] Praszkier, R., \& Nowak, A., 2011. Social Entrepreneurship: Theory and Practice. Cambridge: Cambridge University Press.

[81] Praszkier, R., andNowak, A., 2011. Social Entrepreneurship: Theory and Practice. Cambridge University Press.

[82] Rae, D., 2007. Entrepreneurship: From Opportunity to Action. London: Palgrave Macmillan.

[83] Reynolds, P. D., 1991. Sociology and Entrepreneurship: Concepts and contributions. Entrepreneurship Theory and Practice, 16 (2): 47-70.

[84] Ribeiro-Soriano, D. And Galindo-Martn, M., 2012. Government policies to support entrepreneurship. Entrepreneurship and Regional Development: An International Journal, 24(9-10): 861-864.

[85] Rummler, G. A., and Ramias, A. J., 2010. A framework for defining and designing the structure of work. In J. Vom Brocke, and M. Rosemann (Eds.), Handbook of business process management 1. Introduction, methods and information systems (pp. 83-106). Berlin, Heidelberg: Springer-Verlag.

[86] Sarasvathy, S. D., 2001. Causation and effectuation: Toward a theoretical shift from economic inevitability to entrepreneurial contingency. Academy of Management Review, 26 (2): 243-263.

[87] Schularick, M. and Taylor, A., 2012. Credit booms gone bust monetary policy, leverage, cycles, and financial crises, 18702008. American Economic Review, 102 (2): 5-37.

[88] Schumpeter, J., 1934. Theory of economic development: An inquiry into profits, capital, credit, interest and the business cycle. Cambridge, MA: Harvard University Press.

[89] Shane, S. and Venkataraman, S., 2000. The promise of entrepreneurship as a field of research. Academy of Management Review, 25 (1): 217-226.

[90] Sherman, M., 2009. A Short History of Financial Deregulation in the United States. Centre for Economic Policy Research Working Paper.

[91] Short, H. and Keasey, K., 2005. Institutional shareholders and corporate governance in the UK. In Keasey, K., Thompson, S. and Wright, M. (Eds.), Corporate governance: accountability, enterprise and international comparisons, Chichester: John Wiley and Sons, 61-96.

[92] Smallbone, D., Welter, F., 2012. Cross-border entrepreneurship. Entrepreneurship andRegional Development: An International Journal, 24 (3-4): 95-104.

[93] Stokes, D., Wilson, N., \& Mador, M., 2010. Entrepreneurship. Mason, OH: Cengage Learning Business Press.

[94] Swatinska, A., 2012. Entrepreneurship Culture: The European Perspective and National Perspectives on the Example of Luxembourg. In Eurostat (Ed.), Entrepreneurship determinants: culture and capabilities. Brussels: Eurostat. 
[95] Szabo, A., \& Herman, E., 2012. Innovative Entrepreneurship for Economic Development in EU. Procedia Economics and Finance, 3: 268-275.

[96] Taylor, D. and Thorpe, R., 2004. Entrepreneurial learning: A process of co-participation. Journal of Small Business and Enterprise Development, 11, 2: 203 - 211.

[97] Thorp, H., and Goldstein, B., 2010. Engines of Innovation: The Entrepreneurial University in the Twenty-First Century. The University of North Carolina Press.

[98] Verdujin, K. and Essers, C., 2013. Questioning dominant entrepreneurship assumptions: the case of female ethnic minority entrepreneurs. Entrepreneurship and Regional Development: An International Journal, 23 (9-10): 233-245.

[99] Verheul, I., van Stel, A., Thurik, R., 2006. Explaining female and male entrepreneurship at the country level. Entrepreneurship and Regional Development: An International Journal, 18 (2): 151-183.

[100] Webster, Frederick A., 1977. Entrepreneurs and ventures: an attempt at classification and clarification. The Academy of Management Review, 2 (1): 54-61.

[101] Welpe, I., Sporrle, M., D. Grichnik, D., Michl, T. and Audretsch, D., 2012. Emotions and Opportunities: The Interplay of Opportunity Evaluation, Fear, Joy, and Anger as
Antecedent of Entrepreneurial Exploitation. Entrepreneurship Theory and Practice, 36 (1): 69-96.

[102] Wennberg, K., Pathak, S., and Autio, E., 2013. How Culture Molds the Effects of Self-Efficacy and Fear of Failure of Entrepreneurship. Entrepreneurship and Regional Development, 25 (9-10): 756-780.

[103] Werther, Jr. W. B, Kerr, J. L., and Wright, R. G., 1995. Strengthening corporate governance through board-level consultants. Journal of Organizational Change Management, 8(3): 63-74.

[104] Williams, T. and Green, A., 1997. The business approach to training. Hampshire: Gower Publishing.

[105] Wilson, N. and McLean S., 1994. Questionnaire design: a practical introduction. University of Ulster Press: Newtown Abbery.

[106] Wong, S., 2010. Why Stewardship is Proving Elusive for Institutional Investors. Harvard Law School on Corporate Governance and Financial Regulation, http://corpgov.law.harvard.edu/2010/07/31/why-stewardshipis-proving-elusive-for-institutional-investors/.

[107]Zhao, Y., 2012. World Class Learners: Educating Creative and Entrepreneurial Students. Corwin. 